\title{
Housing as a Social Determinant of Health: Evidence from Singapore, the UK, and Kenya: the 3-D Commission
}

\author{
Meggie Mwoka • Olivia Biermann • Catherine K. Ettman • Salma M Abdalla • Jane \\ Ambuko • Mark Pearson • Sabina Faiz Rashid • Zahra Zeinali • Sandro Galea • Laura \\ Magaña Valladares • Blessing Mberu
}

Accepted: 7 May 2021 / Published online: 3 September 2021

(C) The New York Academy of Medicine 2021

\begin{abstract}
Housing is a paradigmatic example of a social determinant of health, as it influences and is influenced by structural determinants, such as social, macroeconomic, and public policies, politics, education, income, and ethnicity/race, all intersecting to shaping the health and well-being of populations. It can therefore be
\end{abstract}

M. Mwoka • O. Biermann • C. K. Ettman · S. M. Abdalla •

J. Ambuko · M. Pearson · S. F. Rashid · Z. Zeinali ·

S. Galea · L. M. Valladares · B. Mberu

Rockefeller Foundation-Boston University 3-D Commission on

Determinants, Data, and Decision-making, Boston, USA

M. Mwoka

e-mail: meggiemwokz@gmail.com

O. Biermann

e-mail: olivia.biermann@ki.se

C. K. Ettman

e-mail: cettman@bu.edu

J. Ambuko

e-mail: jane.ambuko@uonbi.ac.ke

M. Pearson

e-mail: mark.pearson@oecd.org

S. F. Rashid

e-mail: sabina@bracu.ac.bd

Z. Zeinali

e-mail: zzeinal1@alumni.jh.edu

S. Galea

e-mail: sgalea@bu.edu

L. M. Valladares

e-mail: lmagana@aspph.org

B. Mberu

e-mail: bmberu@aphrc.org

O. Biermann

Department of Global Public Health, Karolinska Institutet, Solna, Sweden argued that housing policy is critically linked to health policy. However, the extent to which this linkage is understood and addressed in public policies is limited and highly diverse across and within countries. This analysis seeks to describe the linkages between housing policies and health and well-being using examples from

\section{K. Ettman \\ Boston University School of Public Health, Boston, USA}

S. M. Abdalla $(\bowtie) \cdot$ S. Galea

Department of Epidemiology, Boston University School of Public Health, Boston, USA

e-mail: abdallas@bu.edu

J. Ambuko

University of Nairobi, Nairobi, Kenya

M. Pearson

OECD, Paris, France

S. F. Rashid

Brac James P Grant School of Public Health, Brac University, Dhaka, Bangladesh

L. M. Valladares

Association of Schools and Programs of Public Health (ASPPH), Washington DC, USA

B. Mberu

African Population and Health Research Center, Nairobi, Kenya 
three countries at different levels of the wealth spectrum: Singapore, the UK, and Kenya.

We conducted a comparative policy analysis across three country contexts (Singapore, the UK, and Kenya) to document the extent to which housing policies address health and well-being, highlighting commonalities and differences among them. To guide our analysis, we used the United Nations (UN) definition of adequate housing as it offers a broad framework to analyze the impact of housing on health and well-being.

The anatomy of housing policies has a strong correlation to the provision of adequate housing across Singapore, the UK, and Kenya, especially for vulnerable groups. The paper demonstrates that contextual factors including population composition (i.e., aging versus youthful), political ideologies, legal frameworks (i.e., welfare versus market-based provision of housing), and presence (or absence) of adequate, quality, timely, reliable, robust data systems for decision-making, which are taken up by stakeholders/state, have strong implications of the type of housing policies developed and implemented, in turn directly and indirectly impacting the overall health and well-being of populations.

This analysis demonstrates the value of viewing housing policies as public health policies that could significantly impact the health and well-being of populations, especially vulnerable groups. Moreover, the findings highlight the importance of the Health in All Policies approach to facilitate integrated policy responses to address social determinants of health such as housing. This is more critical than ever, given the context of the global pandemic that has led to worsening overall health and well-being.

Keywords Housing · Social determinats of health . $\mathrm{SDoH} \cdot$ Policy analysis

\section{Introduction}

The conditions in which people grow, live, work, and age contribute to their health and well-being. These conditions can either be political, social, or economic and are collectively known as the social determinants of health (SDoH). Well-being here refers to a state in which "an individual realizes his or her own abilities, can cope with the normal stresses of life, can work productively and fruitfully, and is able to make a contribution to his or her community." [1]
SDoH not only influence one's health, but also contribute to health inequities between and within countries. Examples of social determinants of health include as follows: employment as it determines an individual's work environment and income levels and the ability to have a safe, secure, healthy workplace and to afford food, housing, and healthcare costs respectively [2].

Housing is a paradigmatic example of a $\mathrm{SDoH}$; it influences and is influenced by structural determinants, such as social, macroeconomic, and public policies, education, income, and ethnicity/race [2]. The burden of substandard housing often falls disproportionately on already vulnerable populations. For example, in the USA, people of color and immigrants face disproportionate challenges in accessing high-quality, affordable housing due to racial and ethnic discrimination $[3,4]$. In Bangladesh, diverse groups of low-income communities struggle to find affordable urban housing, forcing them to live in slums with poor services, located in deplorable conditions and limited tenure security [5]. In most low-income countries, the problem has been exacerbated by loss of income and as a result a rapid rural-urban migration leading to the proliferation of slums and informal settlements in many cities [6].

Housing as a determinant of health differs across and within countries. For example, across low- and middleincome countries (LMICs), over one billion people live in informal settlements, and this number is set to double in the next 15 years. These settlements are characterized by short-supply or non-existent basic services such as water, toilets, sewers, drainage, waste collection, and secure and adequate housing [7-9]. Moreover, informal settlements often lack legal recognition, planning, or formal service provisions. This leads to lack of security of tenure, hinders efforts towards governance and transparency, improved housing conditions, and distorts land prices undermining long-term planning, and reinforces poverty and social exclusion $[10,11]$.

By contrast, in other parts of the world, the growing aging population is driving the restructuring of housing policies and markets to cater for this population. In Japan where $28.1 \%$ of the population is above 65 years, $85 \%$ of this group own their houses. However, in some cases, these houses are not suitably designed to promote independent, safe living in later life including access to amenities [12]. Therefore, those with low income disproportionately lack appropriate housing opportunities to move closers to cities, which offers more convenience like their higher-income counterparts [13]. 
The COVID-19 pandemic has magnified the importance of adequate housing for health and well-being of populations. With lockdowns, curfews, and mandatory quarantines instituted in different extents across the world at the beginning of the crisis, low-income and already vulnerable populations have been disproportionately affected [14-16]. Not only do some of these populations already face homelessness, financial difficulties in paying rent, and insecure tenure, they are also constrained by lack of safe reliable water, sanitation, and adequate space necessary to adhere to COVID-19 safety precautions [17].

People experiencing homelessness are particularly vulnerable to COVID-19 due to lack of regular access to basic facilities such as healthcare, and sanitation and existing comorbidities such as chronic mental and physical conditions [18-20]. In England, outbreaks of COVID-19 in homeless settings are likely to lead to high numbers of new cases among people experiencing homelessness, even if incidence remains low in the general population; further emphasizing the urgency of addressing access to quality and affordable housing now and beyond COVID-19 [21].

Data are essential to inform decision-making around housing. Currently the availability, quality, accessibility, and utilization of data vary across and within countries. In many cities around the world, housing policies have either neglected or often inadequately addressed the needs of homeless and other vulnerable populations such as those living in informal settlements, making it difficult for them to rapidly respond to policy changes to address the impact of COVID-19 [22]. The emergence of "big data" presents an opportunity to tap into diverse types of data to fill existing data gaps, advance our understanding of housing as a $\mathrm{SDoH}$, and improve decision-making needed to inform and influence decision-making, including programs and policies around housing and create a space to demand/enable change and more commitment from the state and stakeholders. Big data approaches provide a mechanism to quickly analyze situations, diagnose and understand underlying problems, predict likely scenarios, and even prescribe the most beneficial potential action. They therefore provide an opportune approach to support data-based decision-making for policy and social change. Lack of data across African cities has been identified as both a hindrance to answering questions critical to the health needs of the urban poor, and to the urban health programming done by implementing agencies and local governments [23, 24]. However, increasing investments in data collection and analyses at local levels have provided windows into understanding SDoH across several African cities that can be adapted and adopted to inform policy and action across the region [25]. For example, the Urban Africa: Risk, Knowledge (Urban ARK) program demonstrates the value of using multiple approaches to gather empirical data that is of practical relevance to local, national, and global decision-makers. \{Other related\} Sources of data include demographic health surveys, health facility data, policy and institutional analysis, community data and mapping, remote sensing, and geospatial data [26]. There remain, however, relatively few such examples worldwide.

In this paper, we build on empirical data to demonstrate the linkages between housing policies and their impact on health and well-being using examples from three counties at different levels of the development spectrum politically, economically, and socially: Singapore, the UK, and Kenya. This allows us to have a rich comparison and identify contextual factors that influence housing as a SDoH across different environments.

\section{Methodology}

We conducted a comparative policy analysis across three country contexts to document the extent to which housing policies address health and well-being, highlighting commonalities and differences among them. Furthermore, we examined how housing programs in these countries are consistent with promoting health and well-being outcomes and health equity. Building on the selected countries, we aimed to demonstrate how some of them are applying big data approaches to understanding the implications of housing on health outcomes and to improve decision-making on housing.

\section{Policy Analysis Approaches}

An internet search of operational housing policy and policy-related documents, statements, and research was conducted. Key search terms included "housing," "housing policy," "affordable housing," "adequate housing," "healthy housing," "housing programs," "housing projects," "public housing," "housing regulations," "Social determinant," "Determinant of health," "housing standards," "legal framework," "Act," "laws," "Institutions," "responsibilities," "Kenya," "United Kingdom," "Singapore," "Cities," "London," and 
"Nairobi." Only articles in English were included. The key search terms were also combined to maximize results generated. Below are the inclusion criteria applied.

1. All government documents or communicated formal positions at the national, subnational, or local level accessible on the internet were included in the review.

2. Documents posted by key housing stakeholders that provided insights into national and city policy formulation processes in the absence of government documents were also included in the review.

3. Experts within and outside the 3-D Commission were also contacted and requested to contribute relevant documents.

This policy analysis aims to highlight the extent to which the concept of housing as a social determinant of health (public health issue) has been framed in existing housing policies. Furthermore, the analysis highlights the extent to which housing policies cover the provision of adequate housing according to UN definition of adequate housing.

To guide our analysis, we used the UN definition of adequate housing as it offers a broad framework to analyze the impact of housing on health and well-being. Below is an extraction tool template for the policy analysis (Table 1). Only official national housing policies were reviewed.

\section{Results}

Singapore

\section{Housing Situation}

About $78 \%$ of Singaporeans today live in public housing estates and $90.4 \%$ of citizens are homeowners [28]. The pillar of the housing sector is the Housing and Development Board (HDB), which was set up as a statutory board in 1960, to provide decent homes equipped with modern amenities for all those who needed them [29]. Public housing policies are considered as instruments to improve housing conditions and human capital development [30].
Table 1 UN definition of adequate housing (UN, 1991) [27]

\begin{tabular}{ll}
\hline Term & Definition \\
\hline Legal security of tenure & $\begin{array}{l}\text { Guarantees legal protection } \\
\text { against forced evictions, } \\
\text { harassment, and other threats; } \\
\text { Including safe drinking water, } \\
\text { materials, facilities, and } \\
\text { infrastructure } \\
\text { adequate sanitation, energy } \\
\text { for cooking, heating, lighting, } \\
\text { food storage, or refuse } \\
\text { disposal; } \\
\text { Unaffordability is currently } \\
\text { measured as the net monthly } \\
\text { expenditure on housing cost } \\
\text { that exceeds } 30 \% \text { of the total } \\
\text { monthly income of the } \\
\text { household } \\
\text { Guarantees physical safety or } \\
\text { provide adequate space, as } \\
\text { well as protection against the } \\
\text { cold, damp, heat, rain, wind, } \\
\text { other threats to health, and } \\
\text { structural hazards } \\
\text { Meet specific needs of } \\
\text { disadvantaged and } \\
\text { marginalized groups are not } \\
\text { taken into account (such as the } \\
\text { poor, people facing } \\
\text { discrimination, persons with } \\
\text { disabilities, victims of natural } \\
\text { disaster) } \\
\text { Housing is not cut off from } \\
\text { employment opportunities, } \\
\text { healthcare services, schools, } \\
\text { childcare centers, and other } \\
\text { social facilities, or if located in } \\
\text { dangerous or polluted sites or } \\
\text { in immediate proximity to } \\
\text { pollution sources; and } \\
\text { Respects and take into account } \\
\text { identity and ways of life }\end{array}$ \\
Accessibility
\end{tabular}

\section{Housing Policies and Implications on Health of Singaporeans}

Housing Policies The government of Singapore developed its housing policies based on three pillars: the establishment of the HDB in 1960, the enactment of the Land Acquisition Act in 1966, and the expansion of the role of the Central Provident Fund (CPF) to become 
a housing finance institution in 1968. The HDB transformed the housing supply side, increasing housing units and housing ownership. Moreover, it was able to price its units below market prices mainly because HDB flats were built on state-owned land, much of which had been acquired from private landowners at below market prices [31]. This was made possible by the Land Acquisition Act, enacted in 1966 [32], which permitted the state to acquire land for any public purpose or for any work which was of public benefit, of public utility, or of the public interest; or for any residential, commercial, or industrial purposes. Finally, the integrated HDB-CPF framework contributed to the growth of housing loans and the development of the mortgage sector leading to rise in homeownership rates [29].

Other relevant housing policies include the Ethnic Integration Policy from 1989 and the Building Control Codes, Acts and Regulations [33, 34]. On the one hand, through the Ethnic Integration Policy, the government utilized its public housing program as an instrument for social integration and nation-building after the country's independence in 1959 [32]. For instance, the policy implemented ethnic quotas within HBD flats and restricted the sell to particular ethnic groups where the quota had been reached [32]. On the other hand, the Building Control Codes, Acts and Regulations [34] promote the adoption of the "Green Mark" criteria, which are aimed at having more environmentally friendly buildings, e.g., in terms of using renewable energy, being water efficient, reducing waste reduction, and making public transport accessible [34].

Affordability Housing affordability is linked to health [35]. In Singapore, studies comparing the Health-related quality of life (HRQoL) between rental and owneroccupied neighborhoods demonstrate that staying in a rental neighborhood, where people typically have a lower socio-economic status, was associated with more mental health problems [35]. Moreover, a study demonstrated that people staying in public rental housing were more likely to be male, require financial assistance, have chronic obstructive pulmonary disease, use anti-depressants and anti-psychotic medications, and have more readmissions and emergency department attendance [36]. Quality of housing also has a crucial role in determining one's housing experiences and thus their quality of life as we will see in the next section [35].
Habitability, Location, and Availability of Services, $M a-$ terials, Facilities, and Infrastructure In Singapore, despite the homogeneity of the neighborhood's built environment, staying in a public rental flat has been correlated with poorer measures of physical and mental health, even after controlling for individual socioeconomic status [37]. Building designs should be established that promote physical, emotional, and mental well-being, especially considering the rapidly aging population. The Singaporean government has established programs such as the Enhancement for Active Seniors, which is a highly subsidized program making homes more elderly friendly, and improving the mobility and comfort for elderly residents [38]. In terms of location, a study by Chan et al. [39] shows that the juxtaposition of low socio-economic status (SES) apartment blocks within communities of higher SES may have negative impact on the mental health status of residents of public rental housings associated with wide disparities in income that may result in diminished trust in the community [39].

Cultural Adequacy The Singaporean government, in collaboration with academic institutions and community organizations, has utilized participatory approaches to design and implement vibrant community spaces that promote social interaction, healthier lifestyles, and bonding for residents of all age [40]. Part of these designs includes linkways that provide sheltered and convenient access, linking blocks to other parts of the estates such as transport, neighborhood shops, other precincts, and town centers. Playgrounds that cater to play and the exercise needs of the elderly, adults, and children, and void decks some of which contain social and community facilities such as childcare centers and elderly day care centers have been created to meet the daily needs of residents [40].

Governance The HDB has collaborated with several governmental agencies in the design and implementation of a built environment that promotes health and well-being for all [41]. For example, the Ministry of Health is working closely with other ministries and the HDB to develop an assisted living model in public housing, where housing is twinned with care services [42]. Moreover, to improve access to healthcare for lowincome citizens, the Ministry of Health has established 
the Community Health Assist Scheme to provide additional subsidies. Recipients of this assistance scheme can seek treatment from private General Practitioners (GP) who are often located within communities where such rental housings are found [39].

\section{UK}

\section{Housing Situation}

The UK offers an interesting case study when it comes to understanding the role of housing policies on overall health and well-being. Not only is the UK comprised of four countries, with key differences on their housing policy approaches, but also offers nuanced understanding on the impact of housing policies on other determinants of health such as race, occupation, and socioeconomic status.

Homes in UK are rented out by private or social landlords. Private landlords are individuals or companies who offer private rented accommodation on the open market, by advertising or using agents. Social landlords are local councils or housing associations that get government help to provide social housing [43, 44]. Social housing refers to rented housing for people who can demonstrate they are in housing need. On the one hand, social housing offers high-quality homes with legal security, as well as low rents and costs [45]. On the other hand, the waiting period to obtain social housing is long and without guarantee of getting the home of choice $[45,46]$.

Affordability The core housing policy issue in the UK is affordability. Over the last 40 years, house prices and rents have grown faster than incomes [47]. Housing costs have thus become unaffordable for many, especially younger and lower-income households [46, 47]. Forty-four percent of people living in social housing were in poverty after housing costs had been considered, while $37 \%$ of them were employed [45]. Forty-five percent of social renting households were in the lowest fifth by income, and only $3 \%$ were in the top fifth. Thirty-seven percent of householders in social renting were in employment, compared to $59 \%$ in the population [45]. Housing affordability has an influence on individual's mental health and well-being. In 2017, 1 in 5 adults in England said a housing issue has negatively impacted their mental health [48]. Supportive housing policies, especially for economically vulnerable populations, could improve mental health $[49,50]$.

Legal Secure Tenure Homeownership in the UK is declining. It stands at $65 \%$ from $71 \%$ in 2004 in England, $62 \%$ from $66 \%$ in 2005 in Scotland, $69 \%$ from $73 \%$ in 2008 in Wales, and 63\% from 67\% in 2006 in Northern Ireland [51-54]. Over the years, social renting has declined, while private renting has increased. Seventeen percent and $13 \%$ of households in England and Wales rent from a private landlord and $18 \%$ and $11 \%$ respectively are renting from a social landlord $[52,55,56]$.

Regional and ethnic differences exist when it comes to home ownership and renting. An example of regional differences is the Scottish government which supports social rented housing, as social renting is common in Scotland, while the UK government rather supports home ownership [54]. In terms of ethnic differences, home ownership is most common among Whites, Indians, or Pakistanis. Moreover, households led by someone born outside the UK are less likely to own their home and more likely to rent privately. These differences showcase underlying social inequalities [52].

Homeownership has been advocated as an important step to individual economic self-sufficiency. In addition, there has been increasing political discourse on homeownership in the UK with policies to boost and protect homeownership, e.g., Help to Buy [57] and Right to Buy [58, 59]. The Help to Buy policy (from 2013) includes a saving account that encourages first time buyers to save for their home, and in return receive a financial boost from the Government. The Right to Buy policy (from the late 1970s) allows tenants in publicly owned council housing to buy their rented accommodation at a heavily subsidized price. Such homeownership policies - though increasing the rate of homeownership - have mainly been demand-side measures, rather than boosting housing supply — leading to unfavorable consequences on the longer term affordability of housing especially to low-income populations, [46] while acknowledging the limitations in evidence on the specific mental health impacts of being unable to access one's tenure of choice. There is emerging evidence that demonstrates a higher level of mental ill health including anxiety and stress among people who are unable to achieve their housing goals [60] and those who experience financial stressors such as being behind on mortgage payments $[49,61]$. 
Accessibility Homelessness remains a significant and growing problem in the UK. Homelessness is disproportionally experienced by migrant groups, e.g., $57 \%$ of homeless persons in London were not from the UK. In the UK, up to $70 \%$ of homeless young people have mental health problems and $33 \%$ self-harm and people with mental health conditions are twice as likely to be homeless as compared to the wider population [62]. At the same time, poor health problems may lead to homelessness which may further exacerbate existing health conditions [63]. The healthcare costs for people who are homeless in England are four times higher for use of acute hospital services and eight times higher for inpatient services compared with the general public [64].

Ethnicity, Disability, and Migration Status and Access to Housing There are large differences in ethnicity, disability, and migration status and access to housing. In social housing, white people made up $83 \%$ of all residents, while the largest minority group were of Black ethnicity (9\%). Among social renting householders, $17 \%$ were registered with a disability, and $49 \%$ had a limiting illness or disability (compared to $8 \%$ and $31 \%$ for people in all tenures) [65].

Asylum seekers and refugees often face destitution and homelessness due to reduced state support [66]. Studies show that they are more likely to experience poor mental health than the local population, including higher rates of depression, post-traumatic stress disorder, and other anxiety disorders [67-69]. The increased vulnerability to mental health problems has been attributed to poor housing, among other factors [70].

Habitability According to the Decent Home Standards Program, a decent home is one that is wind and weather tight, warm, and has modern facilities [71]. Social rented homes were more likely than owned homes and private rented to meet the Decent Homes standard and to be without health and safety hazards, and to have central heating and the best energy efficiency [45]. However, social housing offer less space, higher occupancy rates, and are at more risk of damp, than the other two tenures [45]. Studies in the UK show that overcrowding can lead to psychological distress and mental disorders, especially those associated with a lack of privacy and childhood development [48, 72].
Kenya

\section{Housing and Health Context: a Focus on Informal Settlements}

In Kenya, nearly $61 \%$ of urban house-holds live in informal settlements including slums [73]. This $60 \%$ is crowded onto only $5 \%$ of land. Such settlements are characterized by inadequate access to safe water, inadequate access to sanitation and other infrastructure, poor structural quality of housing, food insecurity, overcrowding, and insecure residential status [73]. It is therefore not unexpected that slum residents have the worst health outcomes of any group in Kenya (including rural residents) [74]. Findings on child mortality indicate that mortality is higher among children born in the slum settlements as compared with those born outside slum, with $60 \%$ of children aged 18-20 months found to be stunted and about a quarter of them $(23 \%)$ were severely stunted. Maternal mortality rate is higher than the national average $[75,76]$.

Beyond health, households in these settlements have limited opportunities for life such as education and employment having low literacy levels and less skills to compete in the formal job market. They endure the near complete absence of governance in their daily lives [74]. In Nairobi, the informal sector employs two-thirds of the city's labor making this population a critical element to the economic landscape of the country [73]. However, in most cases, the government has viewed slums as a drain on the economy rather than a positive and integral part of the urban environment [77].

A number of factors have driven the growth of informal settlements in the country including lack of job opportunities in rural spaces leading to deepening poverty, over-urbanization due to rapid population growth resulting in rural-urban migration, shortages of decent low-income housing, iniquitous patterns of land ownership, lack of land and absence of tenure for the urban poor, use of inappropriate urban planning policies and standards that limit sufficient supply of and access to good quality housing, and poor enforcement of building and zoning laws, leading to deterioration of formal residential areas [77].

Housing Policies To respond to the growth of informal settlements, the government of Kenya has established 
the Kenya Slum Upgrading Programme (KENSUP). KENSUP is aimed at improving the livelihoods of people living and working in slums and informal settlements in the urban areas of Kenya through the provision of security of tenure and physical and social infrastructure as well as providing opportunities for housing improvement and income generation [73]. Additionally, the Government of Kenya (GoK) has committed to deliver a series of ambitious social programs to promote long-term economic development for Kenyan citizens through its Big Four agenda: (1) affordable housing; (2) universal health coverage; (3) enhancing manufacturing; and (4) food security and nutrition. Under the affordable housing agenda, the Kenya government has committed to facilitate mass production of at least $1,000,000$ affordable homes in 5 years (from 2017). The government has committed to partner with financial institutions, private developers, manufacturers of building materials, and cooperatives to deliver homes faster and reduced cost of construction by at least $50 \%$. The affordable units will be constructed across the country and will be equitably distributed [78].

As part of this vision, the State Department for Housing and Urban Development (SDHUD) has been mandated to deliver the Affordable Housing Program (AHP) through the provision of state-owned land for free or at low cost, making provisions to ensure that housing units are offered to Kenyan citizens at an affordable price and creating an environment encourages private sector investment and participation in the Affordable Housing Program [79].

Affordability and Legal Security of Tenure Seventythree percent of slum residents fall below the poverty line [80]. In 2009, just over $10 \%$ of slum households owned their own property, compared to over $15 \%$ in formal areas, which is far below the levels in rural areas [81]. A study showed that rent accounts for $9 \%$ of household expenditures [82]. Adverse events that can put individuals at catastrophic financial risk are a common occurrence. In such situations, the most common coping strategies include as follows: reducing food consumption, use of credit, and removing children from school. Protective factors against such negative coping strategies include having formal employment or owning a business, and owning the dwelling [82]. Thus, legal security of tenure can influence other health determinants such as education and food security.
Unfair land allocation and poor regulation of the urban land market disadvantage poor people, thus forcing them to obtain land informally, through illegal occupancy [83, 84]. Illegal land occupation puts poor people at risk of evictions, obtaining poor-quality housing despite having occupied lands for decades [85]. Moreover, the legal system disadvantages them as it mainly recognizes the rights of title-holders $[85,86]$. As a result, informal settlements are neglected and the health of people continues to be poor compared the rest of the population. Furthermore, permanent features of urban slum living in Kenya, such as forced evictions and dispersing dense slum populations, have been linked in other climes to greater spread of disease among both the displaced populations and the general population as well long-term physical and mental health impacts, especially for women and children [87-89]. To respond to issues of legal security of tenure, under the Affordable Housing Program, the government is offering to low-income households the option of rent-to-own with 25-year tenure and $3 \%$ interest [90].

Habitability, Availability of Services, Materials, Facilities and Infrastructure, and Location Safe water supplies and proper sewage disposal are core to limiting the spread of contagious diseases. In Kenya, only $6 \%$ of households had access to piped water, $51 \%$ shared toilets [91], and three households out of four have no garbage disposal arrangement [9]. Lack of these essential facilities contributes to the high prevalence of infectious disease including respiratory conditions and gastrointestinal issues in slums [92]. A study in two informal settlements in Nairobi shows that people are exposed to high levels of fine particulate matter within their homes, mainly from cooking and lighting fuels and also the smoking of cigarettes indoor [93]. Unregulated slum real estate such as lack of windows in some houses increases their risk of air pollution-related health conditions such as chronic respiratory infections, adverse pregnancy outcomes, such as low birth weight, pre-term births, and still births [93].

Slums have distinctively worse building structures that offer less privacy and are hazardous compared to formal areas [81]. Only $26 \%$ of households live in buildings with a solid wall versus $84 \%$ in formal areas in 2009, and in terms of solid roofs, only $9 \%$ of 
households' buildings have a tile or concrete roof compared to $45 \%$ in formal areas [81]. On average, a household with an average size of about three persons occupies about one rentable room [74]. Housing units in the slums are mainly made of iron sheets providing inadequate protection from heat or cold [82].

Healthcare facilities in slums are virtually non-existent. Majority of individuals have to access private health facilities. Access to private health facilities in turn increases patients' out-of-pocket expenditures, since $90 \%$ of the slum population do not have health insurance [94]. Moreover, lack of security and violence are a serious problem and slum households are more likely to be subject to crime. A study done by Ziraba et al. [95], in two slums in Nairobi, showed homicides accounted for $47 \%$ of all injury-related deaths and firearms $(23 \%)$ and road traffic crashes $(22 \%)$ were the leading single causes of deaths due to injuries. These results show that the pervasively unsafe and insecure environment that characterizes the urban slums contributes significantly to the risk of injury-related mortality [95]. A longitudinal analysis on the causes of death among adults 15 years and above resident in Nairobi informal settlements found a twofold increase in deaths due to injuries, increasing from $11 \%$ in 2003 to $22 \%$ in 2012 , with $54 \%$ of these deaths related to assault [96]. Moreover, a study showed that urban transition and life in the slums are linked to increased psychosocial stress, violence, and insecurity, which can lead to increased risk of CVD [94].

\section{Discussion}

Housing policy is in part health policy. However, the extent to which housing policies speak to health is highly diverse across and within countries. Several dominant themes emerge from our three case studies that contextualize the role of housing in each of these three countries and how data informs policies that can promote health.

\section{Population Composition}

Singapore is a small island state with a population of about 5,700,000 people. Fourteen percent of its population is below 20 years of age while $10 \%$ of its population is 65 years and above [28]. The country is one of the most rapidly aging population in the world with life expectancy standing at 83 years [28]. The UK while having a total population of $66,796,807$, similar to Singapore, has a rapidly rising aging population accounting for $18.5 \%$ of its total population [97]. Kenya on the other hand provides a different picture with $75 \%$ of its total population $(47,564,300$ people) under 35 years of age [98]. In the context of housing, one key vulnerable population that has been identified in the UK are people who are homeless, with young people being the majority [99]. In Kenya, people living in informal settlements are noted to bear a heavier burden when it comes to accessing adequate housing and consequently poorer health outcomes compared to the rest of the population [74]. One of the areas of policy focus in Kenya is on slum upgrading in response to the growth of informal settlements and related deficiencies in services such as health, security, education, and sanitation [73]. While in Singapore the government is responding by putting in place housing options for its elderly populations, in order to improve their accessibility and habitability of their homes, which in turn has a bearing on their physical and mental health, these actions not only reduce chance of injuries but also people's independence. Such population compositional differences have a bearing in terms of contextualizing the understanding of social determinants of health generally and housing particular and associated implications on the health and well-being of a nation.

\section{Political Context}

Political ideologies about housing are reflected in the type of housing policies that are put in place and the government's understanding of their roles and responsibilities [100]. Globally, housing is often considered a commodity and therefore access and provision are driven by market forces, which create systemic differences in housing opportunities shaped by disproportionate access based on one's economic resources, race/ethnicity, or other forms of discrimination [3-5, 100]. Subsequently, these inequalities lead to differences in health outcomes across population sub-groups especially poor, low-income, and ethnic minority households.

In Singapore, housing is considered a core element to human capital development, promotion of health and well-being, and a sense of community [38, 40]. It is perhaps this broad understanding of the implication of housing on health and well-being that led to addressing housing as a public health issue in addition to being addressed as an economic issue. This is reflected in the 
government's policies and programs and the level of multisectoral collaboration between different government sectors. By contrast, in Kenya, housing and health remain highly siloed, with limited multisectoral engagement. Even within the Big Four agenda, there is no clear mention of how health, housing, food, and manufacturing sectors can collaborate in realizing the different goals. It is therefore rare that the social, cultural, environmental, health, and economic facets of housing are addressed in an integrated policy as seen in Kenya's housing policies. Housing is mostly viewed as a commodity and the resulting disparities is a reflection of the wide inequalities between the rich and the poor and the growth of informal settlements that lack basic services necessarily leading to unhealthy lives [77]. Growth of homeownership in the UK and Singapore also reflects political action, motivated by the view that homeownership is an important step to individual economic self-sufficiency. In Kenya, on the other hand, the housing market is primarily a rental market and not a sale market, and thus has lower rates of homeownership [101]. In Nairobi, 91\% of the population rent their homes [90]. The commitment to increase production of affordable housing under the Big Four Agenda is the vision of the current President. Therefore, its continuity to completion may be a challenge when he leaves office in 2022 (his final term); unless, there is political goodwill from the incoming president.

\section{Welfare State Characteristics}

Welfare state characteristics have an impact on health outcomes and inequalities [102]. Eikemo et al. [103] demonstrated that half of the national-level variations of health inequalities between Scandinavian and AngloSaxon countries such as the UK and Ireland and Bismarckian, East European, and Southern European countries is due to welfare characteristics. Looking at our case studies, Singapore operates a unique welfare system which is guided by the philosophy of self-reliance and self-responsibility. That is the individual's socioeconomic support should be derived from one's individual saving, the family, and communities. The government should be the last resort. Therefore, a fundamental pillar of Singapore's social protection system is the Central Provident Fund (CPF) a compulsory saving scheme used to cover expenditures on housing, health, and education to which both employers and employees contribute [104].
The UK government operates a liberal welfare state. 2012 saw the enactment of the Welfare Reform Act which signified government moving away from mechanisms whereby government has been the main source of socio-economic support, to a system that increasingly promotes self-reliance. The Act seeks to improve financial work incentives by ensuring that support is reduced at a consistent and managed rate as people return to work and increase their working hours and earnings [105]. While acknowledging the benefits, mechanisms such as CPF in Singapore and Universal Credit in the UK have had in improving access to housing for some members of the population and therefore likelihood of better health and well-being. It is important to note some of the negative effects they may have especially on the health and well-being of already vulnerable populations. Chan et al. [39] demonstrate that the mandatory nature of the CPF, together with the dominance of the HDB, has likely led to the over-allocation of resources to housing [39]. Consequently, increasing anxiety over the affordability of medical care among residents of public rental housing especially in the screening of chronic diseases [39]. While in the UK the welfare reforms have led to reduced support while rent continues to rise increasing the risk of especially already vulnerable individuals going into poverty and deprivation, and, thus poorer health outcomes [106, 107]. In Kenya, mixed economic ideologies, of government control and private sector led production of housing has led to the challenge of access to land that has sentenced so many citizens to market forces that push land and housing beyond their reach [77]. Limited mechanisms are in place to support low-income individuals to access housing. This is contributed by the low prioritization given to social housing, with preference for marketbased approaches to deliver affordable housing [108, 109]. Moreover, social housing in the country focuses on slum upgrading and redevelopment of old Council estates [108].

Social Justice and Inequities

In the UN Declaration of Human Rights in 1948, housing was articulated as not only a human right but also an important determinant to achieve the right to health and well-being [110]. More recently, in the sustainable development goals, countries committed to making cities and human settlements inclusive, safe, resilient, and sustainable by ensuring access for all to adequate, safe, and affordable housing and basic services and upgrade 
slums by 2030 [111]. However, despite these commitments, issues of social justice and inequality abound in the realm of housing. This is evident in Kenya particularly when it comes to informal settlements. A study by Otiso Kefa [77] highlighted the underlying political economic dynamics of forced evictions in informal settlements. On the surface, forced evictions are caused by conflicts in land rights, non-payment of excessive land and house rents, and urban redevelopment. However, fundamentally, evictions are due to grossly inequitable land ownership structure that make it difficult for the poor to access land and decent shelter [77]. These evictions lead to further personal, emotional and socioeconomic challenges. They increase their risk of homelessness, poor health outcomes and disrupts their social networks and relationships as many scramble to find housing and new places to rent. Therefore, viewing housing through a rights and social justice lens allows a deeper understanding of the deep-seated inequalities, implications of policies, and identification of those most vulnerable and how to address them.

\section{Data Systems and Decision-making}

Presence of adequate, quality, timely, reliable, robust data can clearly delineate population groups that are most left behind, their needs and proper understanding of their health determinants. In Kenya, weak data infrastructure contributes to masking the challenges faced by vulnerable populations such as those in informal settlements [74]. It is against this background that the African Population and Health Research Center (APHRC) established the Nairobi Urban Health and Demographic Surveillance System (NUHDSS) in 2002 in two slum communities (Korogocho and Viwandani) in Nairobi city with the main goal of providing a platform to investigate the long-term social, economic, and health consequences of urban residence focusing on the needs of the urban poor. This platform has highlighted the plight of these populations and a better understanding of their determinants and strategies that need to be taken to improve their health and well-being [74]. In Singapore and UK, robust data systems are able to disaggregate populations and provide a deeper understanding of health determinants and the needs of populations, especially vulnerable groups. This has greatly facilitated the design and implementation of government policies and programs as evidenced by the evolving nature of housing policies and programs that cater to vulnerable populations, e.g., people who are homeless in the UK and aging population in Singapore. While Kenya would be focusing on building data systems, the UK and Singapore are at a stage of harnessing the power of data and digital technologies to better understand $\mathrm{SDoH}$ and to support decision-making. For example, Singapore is leveraging big data and smart technology in planning, designing, and building public housing through a collaboration between the Housing \& Development Board (HDB), the Nanyang Technological University, Singapore (NTU), and the Singapore University of Technology and Design (SUTD). This will be done through using both data from traditional census and surveys, and big data gathered through sensor networks (e.g., human traffic and movement sensors) and social listening [41].

\section{Conclusion}

This paper demonstrates that the health sector is unlikely to achieve significant strides towards better health for all in isolation from the broader social, economic, and political environment - that is, the social determinants of health. Viewing housing through the lens of three countries (Singapore, the UK, and Kenya) with different demographic, socioeconomic, and political context, this paper further emphasizes the importance of contextualizing the SDoH. This exploration of housing as a SDoH through the lens of three countries at different stages of development identifies three themes that are important to contextualizing SDoH, such as housing.

First, using a social justice and equity lens in addressing social determinants of health such as housing ensures that housing policies address the needs of the most vulnerable. Additionally, such an approach further emphasizes the right to housing for all which would address issues such as forced evictions and racial/ethnic discrimination [112]. Second, the case studies demonstrate the impact of differential political determinants of health such as welfare regime characteristics, and political ideologies, in shaping housing policies [102]. Third, the strong association between housing and health emphasizes the importance of a health in all policies approach (HiAP). This refers to a collaborative approach which target the key determinants of health such as housing through integrated policy response across relevant policy areas with the ultimate goal of improving health and health equity [113]. Finally, the paper highlights the importance of robust data systems and/or 
harnessing big data to understand the larger structural and social determinants of health and to facilitate informed decision-making. Taking these issues into account will lead to a richer and more nuanced understanding of social determinants of health across and within countries at different levels of the development spectrum and contextualize the levels of vulnerabilities and risks faced by poor housing conditions across the three countries.

Acknowledgements We thank Leona Ofei for her support formatting this paper. The Rockefeller Foundation-Boston University 3-D Commission (Grant number: 2019 HTH 024).

\section{References}

1. (WHO) World Health Organization. Promoting mental health: concepts, emerging evidence, practice (Summary Report). Geneva: World Health Organization Geneva; 2004.

2. (CSDH) Commission on Social Determinants of Health. Closing the gap in a generation: health equity through action on the social determinants of health. Geneva: World Health Organization; 2008.

3. McConnell ED. Who has housing affordability problems? Disparities in housing cost burden by race, nativity, and legal status in Los Angeles. Race Soc Probl. 2013;5(3) https://doi.org/10.1007/s12552-013-9086-x.

4. Matthew DB, Rodrigue E, Reeves RV. Time for justice: tackling race inequalities in health and housing. Brookings Published. 2016; Accessed July 2, 2020. https://www. brookings.edu/research/time-for-justice-tackling-raceinequalities-in-health-and-housing/

5. Rahaman A. Housing solutions for the urban poor in Bangladesh. UNDP: Published; 2019. Accessed July 2, 2020. https://www.bd.undp.org/content/bangladesh/en/ home/presscenter/pressreleases/2019/04/07/housingsolutions-for-the-urban-poor-in-bangladesh.html

6. (UN-HABITAT) United Nations Human Settlements Programme. World Cities Report 2016 key findings and messages urbanization and development: emerging futures.; 2016; Accessed May 16 2021. https://wcr. unhabitat.org/wp-content/uploads/2017/02/WCR-2016_Abridged-version-1.pdf

7. Lilford RJ, Oyebode O, Satterthwaite D, Melendez-Torres GJ, Chen YF, Mberu B, et al. Improving the health and welfare of people who live in slums. Lancet. 2017;389(10068):559-70. https://doi.org/10.1016/S01406736(16)31848-7.

8. Riley LW, Ko AI, Unger A, Reis MG. Slum health: diseases of neglected populations. BMC Int Health Hum Rights. 2007;7(1) https://doi.org/10.1186/1472-698X-7-2.

9. Emina J, Beguy D, Zulu EM, et al. Monitoring of health and demographic outcomes in poor urban settlements: evidence from the Nairobi Urban Health and Demographic Surveillance System. J Urban Health. 2011;88(S2) https://doi.org/10.1007/s11524-011-9594-1.
10. Durand-Lasserve A. Informal settlements and the millennium development goals: global policy debates on property ownership and security of tenure. Glob Urban Dev. 2006;2(1):1-15.

11. Rashid SF. Strategies to reduce exclusion among populations living in urban slum settlements in Bangladesh. $J$ Health Popul Nutr. 2009;27(4):574-86. https://doi. org/10.3329/jhpn.v27i4.3403.

12. Watanabe M, Tsuji K, Hongo R, Kimura H. How Tokyo's suburban housing became vast ghettoes for the old. The Guardian: Published; 2019. Accessed October 9, 2020. https://www.theguardian.com/cities/2019/jun/11/howtokyo-suburban-housing-blocks-became-ghettoes-for-theold

13. Tsutsui T. Implementation process and challenges for the community-based integrated care system in Japan. Int $J$ Integr Care. 2014;14(1):e002-undefined. https://doi. org/10.5334/ijic. 988 .

14. Banerjee D, Bhattacharya P. The hidden vulnerability of homelessness in the COVID-19 pandemic: perspectives from India. Int J Soc Psychiatry. 2020; https://doi. org/10.1177/0020764020922890.

15. Maxmen A. Coronavirus is spreading under the radar in US homeless shelters. Nature. 2020;581:129-30. https://doi. org/10.1038/d41586-020-01389-3.

16. Corburn J, Vlahov D, Mberu B, Riley L, Caiaffa WT, Rashid SF, et al. Slum health: arresting COVID-19 and improving well-being in urban informal settlements. $J$ Urban Health. 2020;97(3):348-57. https://doi. org/10.1007/s11524-020-00438-6.

17. Baggett TP, Gaeta JM. COVID-19 and homelessness: when crises intersect. Lancet Public Health. 2021;6(4): e193-4. https://doi.org/10.1016/S2468-2667(21)00022-0.

18. Hwang SW, Ueng JJM, Chiu S, Kiss A, Tolomiczenko G, Cowan L, et al. Universal health insurance and health care access for homeless persons. Am J Public Health. 2010;100(8):1454-61. https://doi.org/10.2105 /AJPH.2009.182022.

19. Maremmani AGI, Bacciardi S, Gehring ND, Cambioli L, Schütz C, Jang K, et al. Substance use among homeless individuals with schizophrenia and bipolar disorder. J Nerv Ment Dis. 2017;205(3):173-7. https://doi.org/10.1097 /NMD.0000000000000462.

20. Tsai J, Wilson M. COVID-19: a potential public health problem for homeless populations. Lancet Public Health. 2020;5(4):e186-7. https://doi.org/10.1016/S2468-2667(20 )30053-0.

21. Lewer D, Braithwaite I, Bullock M, Eyre MT, White PJ, Aldridge RW, et al. COVID-19 among people experiencing homelessness in England: a modelling study. Lancet Respir Med. 2020;8:1181-91. https://doi.org/10.1016 /S2213-2600(20)30396-9.

22. Farha L. COVID-19 guidance note protection for those living in homelessness. Accessed April 1, 2020. http://www.unhousingrapp.org/user/pages/07.pressroom/Guidance Note Homelessness Actual Final 2 April 2020[2].pdf

23. African Population and Health Research Center. Population and health dynamics in Nairobi's informal settlements: report of the Nairobi Cross-Sectional Slums Survey (NCSS) 2012.; 2014. 
24. Tacoli C, McGranahan G, Satterthwaite D. World Migration Report 2015. Urbanization, rural-urban migration and urban poverty.; 2014. Accessed May 162021. https://www.iom.int/sites/default/files/our work/ICP/MPR/WMR-2015-Background-Paper-CTacoliGMcGranahan-DSatterthwaite.pdf

25. Ezeh A, Mberu B. Case studies in urban health: Nairobi Kenya. In: Galea S, Ettman CK, Vlahov D, editors. Urban health. New York, NY: Oxford University Press; 2019. p. 330-9.

26. Dodman D, Adelekan I, Brown D, et al. A spectrum of methods for a spectrum of risk: generating evidence to understand and reduce urban risk in sub-Saharan Africa. Area. 2019;51(3) https://doi.org/10.1111/area.12510.

27. United Nations. CESCR General Comment No. 4: The Right to Adequate Housing (Art. 11 (1) of the Covenant). Published online 1991; Accessed May 162021. https://resourcingrights.org/en/document/9c55otxgab9 jyodmjwgdnuq $5 \mathrm{mi}$ ?page $=1$

28. Department of Statistics Singapore. Population and Households data. Accessed November 18, 2020. https://www.singstat.gov.sg/find-data/search-bytheme/households/households/latest-data

29. Phang SY. The Singapore model of housing and the welfare state. In: Housing and the new welfare state: perspectives from East Asia and Europe. 2007:15-44.

30. Chua BH. Welfare developmentalism in Singapore and Malaysia. In: Kwon H, editor. Transforming the developmental welfare state in East Asia. New York, NY: Palgrave Macmillan; 2005. p. 98-117.

31. Phang S-Y. Economic development and the distribution of land rents in Singapore.: a Georgist implementation. Am J Econ Sociol. 1996;55(4):489-501. https://doi.org/10.1111 jj.1536-7150.1996.tb02649.x.

32. Phang SY, Helble MC. Housing policies in Singapore.; 2016. doi:https://doi.org/10.2139/ssrn.2753487

33. Government of Singapore. HDB's Ethnic Integration Policy: why it still matters. Published 2020; Accessed May 16 2021. https://www.gov.sg/article/hdbs-ethnicintegration-policy-why-it-still-matters\#: :text=The $\% 20$ Ethnic\%20Integration\%20Policy\%20applies, of $\% 20$ rental $\% 20$ flats $\% 20$ by $\% 20$ HDB.\&text $=\mathrm{It} \% 20 \mathrm{was} \% 20$ introduced $\% 20$ in $\% 201989$, the $\% 20$ formation $\% 20$ of $\% 20$ racial\%20enclaves

34. Building and Construction Authority (BCA). Codes, acts, and regulations. Accessed October 19, 2020. https://www 1.bca.gov.sg/about-us/news-andpublications/publications/codes-acts-and-regulations

35. Wee LE, Daniel P, Sim A, Lee R, Tay SM, Luo N, et al. Health-related quality of life in a low-socioeconomic status public rental-flat population in Singapore. Appl Res Qual Life. 2018;13(1):179-95. https://doi.org/10.1007/s11482017-9519-6.

36. Low LL, Wah W, Ng MJ, Tan SY, Liu N, Lee KH. Housing as a social determinant of health in Singapore and its association with readmission risk and increased utilization of hospital services. Front Public Health. 2016;4 https://doi.org/10.3389/fpubh.2016.00109.

37. Wee LE, Tsang YYT, Tay SM, et al. Perceived neighborhood environment and its association with health screening and exercise participation amongst low-income public rental flat residents in Singapore. Int J Environ Res Public Health. 2019;16(8):1384. https://doi.org/10.3390 /ijerph16081384.

38. Housing \& Development Board (HDB). Enhancement for Active Seniors (EASE). Accessed October 19, 2020. https://www.hdb.gov.sg/cs/infoweb/residential/living-inan-hdb-flat/for-our-seniors/ease

39. Chan CQH, Lee KH, Low LL. A systematic review of health status, health seeking behaviour and healthcare utilisation of low socioeconomic status populations in urban Singapore. Int $J$ Equity Health. 2018;17(1):39. https://doi.org/10.1186/s12939-018-0751-y.

40. Housing \& Development Board (HDB). Your Community Spaces . Accessed October 19, 2020. https://www.hdb.gov. $\mathrm{sg} / \mathrm{cs} /$ infoweb/community/creating-vibrant-places/yourcommunity-spaces

41. OpenGov. HDB Singapore partners with local universities to leverage big data and smart technology in planning, designing and building public housing . Published 2017. Accessed October 1, 2020. https://opengovasia.com/hdbsingapore-partners-with-local-universities-to-leverage-bigdata-and-smart-technology-in-planning-designing-andbuilding-public-housing/

42. Ministry of Health Singapore. Transforming our healthcare system to meet evolving needs . Published 2020. Accessed October 18, 2020. https://www.moh.gov. $\mathrm{sg} /$ docs/librariesprovider5/cos2020/cos-2020\%2D\%2Dtransforming-our-healthcare-system-to-meet-evolvingneeds.pdf

43. Chartered Institute of Housing. Housing in England explained | Housing Rights Information (England \& Wales). Accessed May 16 2021. https://www.housing-rights. info/02_1_Housing_explained.php

44. Chartered Institute of Housing. Housing in Scotland explained | Housing Rights Information (Scotland). Accessed May 16 2021. https://www.housing-rights.info/housing-inscotland-explained.php

45. Tunstall R, Pleace N. Social housing: evidence review: University of York. New York (England): Centre for Housing Policy University of York; 2018.

46. Keohane N, Broughton N. The politics of housing . Social Market Foundation. Published 2013. Accessed October 28, 2020. https://www.smf.co.uk/publications/the-politics-ofhousing/

47. Hilber CAL, Vermeulen W. The impact of supply constraints on house prices in England. Econ $J$. 2016;126(591):358-405. https://doi.org/10.1111 lecoj. 12213.

48. Shelter UK. The impact of housing problems on mental health. Published 2017; Accessed May 162021. https://england.shelter.org.uk/_data/assets/pdf_file/0008 /1397267/2017_04_19_Research_Report_-_The_impact_ of housing problems on mental health.pdf

49. Curl A, Kearns A. Can housing improvements cure or prevent the onset of health conditions over time in deprived areas? BMC Public Health. 2015;15(1):1191. https://doi. org/10.1186/s12889-015-2524-5.

50. Taylor MP, Pevalin DJ, Todd J. The psychological costs of unsustainable housing commitments. Psychol Med. 2007;37(7):1027-36. https://doi.org/10.1017 /S0033291706009767. 
51. Housing Executive. Housing market analysis update.; 2017; Accessed May 16 2021. https:/www.belfastcity. gov.uk/getmedia/c10df2b8-de71-4a42-a1ed-3893753c37 b6/DPS024_Evi-01.pdf

52. Barton C. Home ownership and renting: demographics. Published online 2017. Accessed October 28, 2020. https://commonslibrary.parliament.uk/researchbriefings/cbp-7706/

53. Grannum C. Policy briefing: Home ownership. London. Shelter. 2006 April; Accessed May 16 2021. https://assets. c t f a s s e t s. net/6 s x v m n d n p n 0 s/s 8 xfxQuwYpZZZojzDVypT/fa0df50c2f98306515ee550006 df3ba7/Policy_Briefing-Home_Ownership.pdf

54. SPICe Spotlight. Buying a home: trends in home ownership and Scottish Government support . SPICe Spotlight | Solas air SPICe. Published 2018. Accessed October 28, 2020. https://spice-spotlight.scot/2018/09/19/buying-ahome-trends-in-home-ownership-and-scottishgovernment-support/

55. UK private rented sector: 2018. Office for National Statistics. Published 2019; Accessed May 16 2021. https://www.ons. gov.uk/economy/inflationandpriceindices/ articles/ukprivaterentedsector/2018

56. Ministry of Housing, Communities and Local Government. Social housing lettings: April 2018 to March 2019, England. Published 2020; Accessed May 16 2021. https://assets.publishing.service.gov. uk/government/uploads/system/uploads/attachment data/file/861471/Social_Housing_Lettings_in_England_ April_2018_to_March_2019.pdf

57. Help to Buy. Accessed October 28, 2020. https://www. helptobuy.gov.uk/

58. Clarke A, Jones M, Oxley M, Udagawa C. Understanding the likely poverty impacts of the extension of Right to Buy to housing association tenants. Cambridge Centre for Housing and Planning Research: Published; 2015. Accessed October 25, 2020. https://www.cchpr.landecon. cam.ac.uk/Research/Start-Year/2015/Understandinglikely-poverty-impacts-of-extension-Right-to-Buy-HAtenants/Project-Report

59. Shelter UK. House of Commons - Transport. Local Government and the Regions. UK parliament: Published; 2002. Accessed October 29, 2020. https://publications. parliament.uk/pa/cm200102/cmselect/cmtlgr/809/809 m63.htm

60. McKee K, Soaita AM. The 'frustrated' housing aspirations of generation rent. Glasgow, England: University of Glasgow \& UK Collaborative Centre for Housing Evidence; 2018.

61. Downing J. The health effects of the foreclosure crisis and unaffordable housing: a systematic review and explanation of evidence. Soc Sci Med. 2016;162:88-96. https://doi. org/10.1016/j.socscimed.2016.06.014.

62. Rees S. Mental ill health in the adult single homeless population a review of the literature.; 2009; Accessed May 16 2021. https://www.crisis.org.uk/media/20611 /crisis mental_ill_health 2009.pdf

63. Leng $\overline{\mathrm{G}}$. The impact of homelessness on health.; 2017; Accessed May 16 2021. https://www.local.gov. uk/sites/default/files/documents/22.7\%20HEALTH\%20 AND\%20HOMELESSNESS_v08_WEB_0.PDF
64. O'hare R, Spicer T, Sweeney M. Rough sleepers: health and healthcare a review of the health needs and healthcare costs of rough sleepers in the London boroughs of Hammersmith and Fulham, Kensington and Chelsea, and Westminster.; 2013; Accessed May 16 2021. https://www. jsna.info/sites/default/files/Rough\%20Sleepers $\% 20$ Health\%20and\%20Healthcare\%20Summary.pdf

65. Disability and housing, UK; 2019. Office for National Statistics. Published 2019; Accessed May 162021. https:/www.ons.gov.uk/peoplepopulationandcommunity/ healthandsocialcare/disability/bulletins/ disabilityandhousinguk/2019\#main-points

66. Refugee Council UK. Top 10 facts from the latest statistics on refugees and people seeking asylum. Refugee Council: Published; 2020. Accessed October 28, 2020. https://www. refugeecouncil.org.uk/information/refugee-asylumfacts/top-10-facts-about-refugees-and-people-seekingasylum/

67. Tribe R. Mental health of refugees and asylum-seekers. Adv Psychiatr Treat. 2002;8(4):240-7. https://doi. org/10.1192/apt.8.4.240.

68. Fazel M, Wheeler J, Danesh J. Prevalence of serious mental disorder in 7000 refugees resettled in western countries: a systematic review. Lancet. 2005;365(9467):1309-14. https://doi.org/10.1016/S0140-6736(05)61027-6.

69. Blackmore R, Boyle JA, Fazel M, et al. The prevalence of mental illness in refugees and asylum seekers: a systematic review and meta-analysis. Spiegel P, ed. PLoS Med. 2020;17(9):e1003337. https://doi.org/10.1371/journal. pmed.1003337.

70. Porter M, Haslam N. Predisplacement and postdisplacement factors associated with mental health of refugees and internally displaced persons: a meta-analysis. JAMA. 2005;294(5):602-12. https://doi.org/10.1001 /jama.294.5.602.

71. Department for Communities and Local Government. A decent home: Definition and guidance for implementation. London; Accessed 2006 June. https://assets.publishing. service.gov.uk/government/uploads/system/uploads/ attachment_data/file/7812/138355.pdf

72. Reynolds L. Full house? How overcrowded housing affects families. Shelter, 2005. Accessed May 162021. https://assets.ctfassets.net/6sxvmndnpn0s/6dU8FFbZ6 RnSk6DbnDOMHb/61e30884aff47a789891b2dce54 fcbc7/Full_house_overcrowding_effects.pdf

73. United Nations Human Settlements Programme (UNHABITAT). UNHABITAT and the Kenya Slum Upgrading Programme. Nairobi, Kenya: United Nations Human Settlements Programme UNHABITAT; 2007.

74. Beguy D, Elung'ata P, Mberu B, et al. HDSS profile : the Nairobi Urban Health and Demographic Surveillance System (NUHDSS ). Int J Epidemiol. 2015:1-10.

75. Kenya National Bureau of Statistics (KNBS), ICF Macro. Kenya Demographic and Health Survey 2008-09.; 2010.

76. Ziraba AK, Madise N, Mills S, Kyobutungi C, Ezeh A. Maternal mortality in the informal settlements of Nairobi city: what do we know? Reprod Health. 2009;6(1) https://doi.org/10.1186/1742-4755-6-6.

77. Otiso KM. Forced evictions in Kenyan cities. Singap $J$ Trop Geogr. 2003;23(3):252-67. https://doi.org/10.1111 /1467-9493.00130. 
78. The Big 4 - empowering the nation. Accessed May 16 2021. https://big4.delivery.go.ke/

79. The 500,000 Affordable Housing Programme. Boma Yangu. Accessed May 16 2021. https://bomayangu.go.ke/

80. World Bank. Kenya inside informality: poverty, jobs, housing and services in Nairobi's slum. Washington, DC: World Bank Group; 2006.

81. Bird J, Montebruno P, Regan T. Life in a slum: understanding living conditions in Nairobi's slums across time and space. Oxf Rev Econ Policy. 2017;33(3):496-520. https://doi.org/10.1093/oxrep/grx036.

82. Amendah DD, Buigut S, Mohamed S. Coping strategies among urban poor: evidence from Nairobi, Kenya. PLoS One. 2014;9(1):e83428. https://doi.org/10.1371/journal. pone. 0083428 .

83. United Nations Human Settlements Programme (UNHabitat). The challenge of slums.; 2003; Accessed May 16 2021. https://www.un.org/ruleoflaw/files/Challenge\%20 of $\% 20$ Slums.pdf

84. Mwau B, Sverdlik A. High rises and low-quality shelter: rental housing dynamics in Mathare Valley. Nairobi Environ Urban. 2020;32(2):481-502. https://doi. org/10.1177/0956247820942166.

85. Apiyo L. Land-grabbing and evictions in Kenya. Habitat Debate. 1998;4(1):18-9.

86. Mwangi W. Security of tenure in urban settlements in Kenya: issues at play. St Gallen, Switzerland: Swiss Centre for Development Cooperation in Technology and Management; 2000. from Skat website: https://skat. ch/aboutus/.

87. Osorio L, Todd J, Bradley DJ. Travel histories as risk factors in the analysis of urban malaria in Colombia. Am J Trop Med Hyg. 2004;71(4):380-6. https://doi. org/10.4269/ajtmh.2004.71.380.

88. Kim G, Torbay R, Lawry L. Basic health, women's health, and mental health among internally displaced persons in Nyala Province, South Darfur. Sudan Am J Public Health. 2007;97(2):353-61. https://doi.org/10.2105 /AJPH.2005.073635.

89. Choueiry N, Khawaja M. Displacement and health status in low income women: findings from a population-based study in greater Beirut. J Migr Refug Issues. 2007;3(1):1-13.

90. Ministry of Transport Infrastructure Housing and Urban Development. 500,000 Affordable Homes Program.; 2019; Accessed May 16 2021. https://bomayangu.go. ke/downloads/20190401_Affordable_Housing_Program_Delivery_Framework_Draft_v02.pdf

91. Elung'ata $\bar{P}$. Shared toilets in the Nairobi Urban Health and Demographic Surveillance System. In: Amendah D, editor; 2013.

92. Gulis G, Mulumba JAA, Juma O, Kakosova B. Health status of people of slums in Nairobi Kenya. Environ Res. 2004;96(2):219-27. https://doi.org/10.1016/j. envres.2004.01.016.

93. Muindi K, Kimani-Murage E, Egondi T, Rocklov J, Ng N. Household air pollution: sources and exposure levels to fine particulate matter in Nairobi slums. Toxics. 2016, 4(3):12. https://doi.org/10.3390/toxics4030012.

94. van de Vijver S, Oti S, Oduor C, Ezeh A, Lange J, Agyemang C, et al. Challenges of health programmes in slums. Lancet. 2015;386(10008):2114-6. https://doi. org/10.1016/S0140-6736(15)00385-2.

95. Ziraba AK, Kyobutungi C, Zulu EM. Fatal injuries in the slums of Nairobi and their risk factors: results from a matched case-control study. J Urban Health. 2011;88(S2): 256-65. https://doi.org/10.1007/s11524-011-9580-7.

96. Mberu B, Wamukoya M, Oti S, Kyobutungi C. Trends in causes of adult deaths among the urban poor: evidence from Nairobi Urban Health and Demographic Surveillance System, 2003-2012. J Urban Health. 2015;92:422-45. https://doi.org/10.1007/s11524-015-9943-6.

97. Office for National Statistics (ONS). People, population and community. Published 2020. Accessed October 27, 2020. https:/www.ons.gov.uk/peoplepopulationandcommunity

98. Kenya National Bureau of Statistics (KNBS). Kenya Population and Housing Census. Volume III: Distriibution of Population by Age and Sex.; 2019; May 16 2021. https://www.knbs.or.ke/?wpdmpro=2019-kenyapopulation-and-housing-census-volume-iii-distribution-ofpopulation-by-age-sex-and-administrative-units

99. Diaz R. Young people and homelessness. London. Shelter. 2005 November; Accessed May 16 2021. https://england. shelter.org.uk/professional_resources/policy_and research/policy_library/young_people_and homelessness_factsheet

100. Satterthwaite D. Editorial: Getting housing back onto the development agenda: the many roles of housing and the many services it should provide its inhabitants. Environ Urban. 2020;32(1):3-18. https://doi.org/10.1177 /0956247820905212.

101. Centum. Realities of Kenya's housing market. Vol. 2.; 2019; Accessed May 16 2021. https://centumre.co.ke/wpcontent/themes/centum_re/research_reports/Realities_of_ Kenya_RE_Market.pdf

102. Muntaner C, Borrell C, Ng E, Chung H, Espelt A, Rodriguez-Sanz M, et al. Politics, welfare regimes, and population health: controversies and evidence. Sociol Health Illn. 2011;33(6):946-64. https://doi.org/10.1111 j.1467-9566.2011.01339.x.

103. Eikemo TA, Bambra C, Judge K, Ringdal K. Welfare state regimes and differences in self-perceived health in Europe: a multilevel analysis. Soc Sci Med. 2008;66(11):2281-95. https://doi.org/10.1016/j.socscimed.2008.01.022.

104. Lee SA, Qian J. The evolving Singaporean welfare state. Soc Policy Adm. 2017;51(6):916-39. https://doi. org/10.1111/spol.12339.

105. Department for Works and Pension. 2010 to 2015 government policy: welfare reform. Published 2015; Accessed May 16 2021. https://www.gov.uk/government/publications/2010to-2015-government-policy-welfare-reform/2010-to-2015government-policy-welfare-reform

106. Clarke A, Morris S, Williams P. How do landlords address poverty? A poverty-focused review of the stratetgies of local authorities, landlords and letting agents in England. Cambridge Centre for Housing \& Planning Research: Published; 2015. Accessed October 25, 2020. https://www.cchpr.landecon.cam.ac.uk/Research/StartYear/2013/Poverty-Focused-Review/How-do-landlordsaddress-poverty

107. Fuller-Thomson E, Hulchanski JD, Hwang S. The housing/ health relationship: what do we know? Rev Environ Health. 
2000;15(1-2):109-33. https://doi.org/10.1515 /REVEH.2000.15.1-2.109.

108. Economic and Social Rights Center. State of housing in Kenya: will government strategy deliver on social housing?; 2018; Accessed May 16 2021. https://s3-eu-west-1. amazonaws.com/s3.sourceafrica.net/documents/118447 /State-of-Housing-Book-2.pdf

109. Omenya A. State of housing in Kenya: will government strategy deliver on social housing?; 2018; Accessed May 16 2021. http://bit.ly/2kAXDrW

110. United Nations. United Nations human rights declaration.; 1948; Accessed May 16 2021. https:/www.ohchr.org/EN/ UDHR/Documents/UDHR_Translations/eng.pdf

111. United Nations. United Nations. Sustainable development goals. Published online 2015; Accessed May 162021. https://sdgs.un.org/goals
112. World Health Organization (WHO). Social determinants of health sectoral briefing series 1 housing: shared interests in health and development. Geneva: World Health Organization; 2011.

113. World Health Organization (WHO). Progressing the sustainable development goals through health in all policies : case studies from around the world.; 2017; Accessed May 16 2021. https://www.who.int/social_determinants/ publications/progressing-sdg-case-studies-2017.pdf

Publisher's Note Springer Nature remains neutral with regard to jurisdictional claims in published maps and institutional affiliations. 